\title{
Do prospective primary school teachers suffer from Foreign Language Anxiety (FLA) in Spain?
}

\author{
Marian Amengual-Pizarro \\ Universitat de les Illes Balears (UIB), Spain \\ marian.amengual@uib.es
}

\begin{abstract}
The main aim of this study is to investigate Foreign Language Anxiety (FLA) in relation to the teaching and learning of English as a foreign language. A total of 75 prospective primary school teachers at the University of the Balearic Islands (UIB) took part in this study. A small questionnaire that included the Foreign Language Classroom Anxiety Scale (FLCAS) (Horwitz et al., 1986) was used to collect data. The results of this study show that most participants experience average and high anxiety levels in the language classroom. Communication apprehension was reported to be the main source of FLA, followed by fear of negative evaluation and test anxiety. The findings also revealed the strong association between FLA, motivation, language proficiency and degree of self-confidence. Furthermore, the data indicate that the primary source of speaking anxiety is related to participants' lack of English proficiency. This may have potential adverse effects on the confidence levels of L2 teachers, their target language use, and their instructional competence (Horwitz, 1996).
\end{abstract}

Keywords: Foreign Language Anxiety (FLA), prospective primary school teachers, foreign/second language learning, English teaching, Spanish EFL students.

\section{Resumen}

El principal objetivo de este trabajo es investigar la ansiedad lingüística vinculada a la enseñanza y aprendizaje de la lengua inglesa como lengua extranjera. Un total de 75 futuros profesores de primaria de la Universitat de les Illes Balears (UIB) participaron en este estudio. Se diseñó un breve cuestionario que incluía la Foreign Language Classroom Anxiety Scale (FLCAS) (Horwitz et al., 1986) para recoger los datos. Los resultados 
de este estudio demuestran que la mayoría de participantes experimentan niveles de ansiedad medios y altos en la clase de lengua extranjera. La aprensión comunicativa es la fuente principal de dicha ansiedad seguida por el miedo a la evaluación negativa y la ansiedad ante los exámenes. Los resultados también demuestran la fuerte asociación entre la ansiedad lingüística, la motivación, el dominio de la lengua y el nivel de auto-confianza. Además, los datos indican que la principal fuente de ansiedad está relacionada con el escaso dominio de la lengua inglesa. Esto puede tener efectos potencialmente negativos en los niveles de confianza de los profesores de segundas lenguas, su uso de la lengua meta en clase y su competencia pedagógica (Horwitz, 1996).

Palabras clave: Ansiedad lingüística, futuros profesores de primaria, aprendizaje de segundas lenguas, enseñanza del inglés, aprendices españoles de inglés como lengua extranjera.

\section{Introduction}

In the field of language education, the relevance of affective variables has long been recognised (Phillips, 1992; Dewaele, 2005; Pavlenko, 2011). Among them, Foreign Language Anxiety (FLA) has been the focus of much research attention since this affective variable is believed to exert negative influence on foreign or second language (L2) learning by interfering with the successful development of the target language (Krashen, 1985; MacIntyre \& Gardner, 1991; Onwuegbuzie et al. 2000; Scovel, 2001; Horwitz, 2001; Williams \& Andrade, 2008; Liu, 2013).

FLA is described as a complex psychological construct linked to a specific type of context or situation (Horwitz et al., 1986; MacIntyre \& Gardner, 1989). Horwitz et al. (1986: 128) defined FLA as "a distinct complex construct of self-perceptions, beliefs, feelings, and behaviours related to classroom language learning arising from the uniqueness of the language learning process". FLA is then characterised as a situationspecific type of anxiety (independent of any other type of anxiety) prompted by L2 learning contexts. Although various studies (Spielmann \& Radnofsky, 2001; Dörnyei, 2005) reveal that some degree of FLA may have a positive or beneficial influence on language learning (i.e. facilitating anxiety), most research findings point to the negative effects of language anxiety (i.e. debilitating anxiety) on L2 effective development (Cheng et al., 1999; Horwitz, 2000, 2001; Onwuegbuzie et al., 2000; Scovel, 2001; Gregersen 2003; Elkhafaifi, 2005). These negative feelings may be manifest in physical symptoms such as sweating, headaches, heart palpitations or other emotional reactions such as frustration, lack of concentration, excessive worry, forgetfulness, absenteeism, etc., which may have an adverse effect on the learning of the L2 regardless of language 
teaching methodology (Horwitz \& Young, 1991; Aida, 1994; MacIntyre 1999; Casado \& Dereshiwsky, 2001; Gregersen, 2007; Williams \& Andrade, 2008; Liu, 2013).

FLA has been associated with specific language skills such as speaking, listening, writing or reading (Sellers, 2000; Cheng, 2002; Elkhafaifi, 2005; Woodrow, 2006). However, speaking is usually regarded as the greatest source of FLA in the classroom since L2 students must try to express and communicate themselves in a language they do not fully master (Horwitz et al., 1986; MacIntyre \& Gardner, 1991; Phillips, 1992; Young, 1992; Aida, 1994; Matsuda \& Gobel, 2004; Woodrow, 2006; Criado \& Mengual, 2017). This may challenge the image students have of themselves as competent speakers, causing tension, worry and frustration (Ortega-Cebreros, 2003; Arnaiz-Castro \& Guillén, 2013; Al-Saraj, 2014). As a result, anxious students are more likely to avoid participating and engaging in activities that may be perceived as more complex or risky when using the L2 (MacIntyre \& Gardner, 1991, 1994; Aida, 1994; Sheen, 2008), thus missing crucial opportunities to improve their oral communication skills in the target language (Gregersen, 2007; Kim, 2009; Arnaiz \& Guillén, 2012). Due to their especially communicative-oriented approach and interactive nature, foreign language classroom situations are therefore regarded as particularly anxietyinducing contexts (Yang, 2012).

Horwitz et al. (1986) designed a self-report instrument, the Foreign Language Classroom Anxiety Scale (FLCAS), to measure the level of anxiety experienced by learners in L2 classroom settings. Although the FLCAS deals with general foreign language anxiety, particular emphasis is placed on speaking and listening, since these skills have been found to be the most substantially affected by FLA. Horwitz et al. (1986) associate FLA with three main interrelated anxiety constructs: communication apprehension, test anxiety, and fear of negative evaluation. Communication apprehension refers to the type of anxiety experienced when communicating with people in the L2, which may result in frustration and self-consciousness in some students. Test anxiety is related to fear of failing in tests. Test-anxious students are likely to be afraid of making mistakes since they associate the L2 classroom to testing situations rather than to communicative learning environments (Gregersen $\&$ Horwitz, 2002). Finally, fear of negative evaluation arises from an excessive worry about being evaluated negatively by others. Students who suffer from this latter type of performance anxiety tend to avoid using the L2 to prevent negative personal and academic judgements from other people. According to Horwitz et al. (1986), these three main interrelated factors are shown to influence the effectiveness of language learning.

Language anxiety also seems to be interrelated with other affective variables such as motivation. In fact, numerous studies have found significant negative correlations 
between FLA and motivation (Clément et al., 1994; Rodriguez \& Abreu, 2003). Research suggests that motivated students tend to be less anxious when learning the foreign language, and are also willing to put more effort into learning tasks. In other words, motivation appears to promote the learning of the target language whereas FLA is likely to hinder language development and achievement. Other variables such as gender (Aida, 1994; Bekleyen, 2009; Park \& French, 2013; Öztürk, 2016), course grades (Arnaiz-Castro \& Guillén, 2012, 2013), prior experience, and perceived selfproficiency have also been shown to have an influence on FLCA (Horwitz et al., 1986; Matsuda \& Gobel, 2003; Phillips, 2003; Elkhafaifi, 2005; Kongchan \& Wareesiri, 2008).

Most of the research studies on FLA conducted so far have focused on language anxiety experienced by L2 learners rather than by L2 teachers. However, Horwitz (1996) placed special emphasis on the harmful effects of FLA on non-native language teachers, who are also identified as foreign language learners regardless of their advanced level of English proficiency. Horwitz explains that the process of learning an L2 is never finished, and many non-native teachers of the language suffer from anxiety when using the foreign language. Teachers with high levels of anxiety are likely to make little use of the target language in class, which may affect the quality of classroom instruction, and contribute to reduce teachers' self-confidence. According to Horwitz (1996: 366): "Foreign language anxiety can inhibit a teacher's ability to effectively present the target language, interact with students, and serve as a positive role model as a language learner". In the same vein, Williams (1991) concluded that anxious teachers are shown to be less effective in their instructional practices. Thus, FLA seems to be a potentially negative factor influencing the quality of language instruction.

Today's emphasis on communicative-oriented approaches has placed increasing pressure on L2 teachers who need to demonstrate a high level of proficiency in the target language so as to be able to respond effectively to the linguistic needs of L2 students (Zheng, 2008; Amengual-Pizarro, 2013). In fact, research has related FLA experienced by L2 teachers to general language proficiency and oral communication skills, which have been found to be especially anxiety-provoking factors (Horwitz et al., 1986, Horwitz, 1996). Thus, Kim \& Kim (2004) concluded that, among other variables, the limited linguistic proficiency of L2 student teachers as well as their lack of self-confidence while being compared to native teachers were identified as some of the main sources of teaching anxiety. Ípeck (2007) also related FLA experienced by $\mathrm{L} 2$ teachers to making mistakes while using the target language as well as to being compared with native speakers of the language. Among the different language skills, speaking and listening seem to be the main causes for concern to student teachers while teaching a foreign language. Other stress-related factors associated to the level of 
anxiety of L2 teachers are also motivation and teaching experience (Ortega-Cebrero, 2003; Rodríguez \& Abreu, 2003; Gagliardi \& Maley, 2010; Arnáiz-Castro \& Guillén, 2013).

In light of the importance of FLCA on L2 development and achievement, there is a need to conduct further research on foreign language teaching anxiety. To date, investigations into FLA experienced by prospective primary school teachers are clearly scarce. However, understanding and identifying the causes of this affective variable is of paramount importance in order to enhance L2 teaching and learning (Williams, 1991; Horwitz, 1996). Furthermore, within the trend towards the internationalization of Spanish universities, knowledge of the English language has become a compulsory degree requirement for all student teachers, regardless of their chosen specialised subjects (i.e. Tutorial Action, Language and Audition, Physical Education, Arts and Musical Education, etc.). The generalist orientation of teacher education programmes in Spain also allows primary school teachers holding a B1 or B2 certificate of English proficiency (Common European Framework of Reference for Languages, CEFR, 2001) to teach English at primary school level, irrespective of the specialist training they may have completed. On this basis, and given the key role the learning of English plays in today's world, it is essential to explore the FLA construct from a L2 student teachers' perspective in order to promote the English proficiency of primary school teachers, and encourage the development of anxiety-reducing strategies that may lead to the creation of more supportive and effective L2 learning environments.

\section{Research questions}

In spite of the relevant role FLA plays in L2 teaching and learning, there has been a shortage of research that addresses FLA in Spain. Most of these studies have been conducted in secondary schools (Ortega-Cebreros, 2003; Martínez Agudo, 2013; Criado \& Mengual, 2017) and Official Language Schools (Pérez-Paredes \& MartínezSánchez, 2000-2001). Only a few studies have explored FLA towards English as a foreign language in a university context (Arnaiz-Castro \& Guillén, 2012, 2013). In fact, to the best of the author's knowledge, studies which specifically investigate foreign language teaching anxiety in Spanish universities are practically absent (see Arnaiz-Castro \& Guillén, 2013). Therefore, this study aims to address this research gap by examining the level of FLCA experienced by Spanish pre-service teachers while learning English as a foreign language and the main variables associated with their language anxiety levels. Specifically, the following research questions were posed:

1) What level of FLCA do prospective primary school teachers have towards the learning of English? 
2) What is the main source of FLCA among future primary school teachers?

3) Are there any differences in the degree of FLCA that participants experience across different formative itineraries or specialised education programmes?

4) Is FLCA affected by participants' gender, and level of English language proficiency?

5) What are the main sources of FLCA reported by student teachers when using the English language?

\section{Method}

\subsection{Participants}

The participants in this study were all second-year prospective teachers studying on a four-year university degree in Primary School Education at the University of the Balearic Islands (UIB), Spain. A total of 75 students enrolled in a compulsory English degree course, 'English language and teaching II', awarded 6 ECTS (European Credit Transfer System) credits, took part in this study. This English language course aims to help student teachers to satisfy the mandatory requirement for all undergraduates to attain a B2 level of English proficiency (CEFR) before graduation, regardless of their chosen specialised subjects. Previously, participants had all taken a compulsory English course during their first year studies, 'English language and teaching I' (of 6 ECTS credits) at B1 level of English proficiency (CEFR), as part of their bachelor's degree requirements. None of the respondents in this study were native speakers of English.

The sample consisted of $63(84 \%)$ females and $12(16 \%)$ males. With regard to age, the majority of respondents $(84.9 \%)$ were between 19 and 25 years of age, $9.6 \%$ of the respondents were between 26 and 35 years, $4.1 \%$ were between 36 and 45 years old and $1.4 \%$ were older than 45 years.

\subsection{Instrument and data collection}

The data for this study were collected by means of a questionnaire which was administered to all participants in mid-February 2018. The questionnaire included three different sections. The first section consisted of background information regarding participants' gender, age, and their university entrance examination marks 
in the English Test (ET). The Spanish translated version of the Foreign Language Classroom Anxiety Scale (FLCAS) developed by Horwitz et al. (1986) was included in the second section of the questionnaire (see Pérez-Paredes \& Martínez Sánchez, 2000-2001). The FLCAS is the most widely accepted self-report measure of general foreign language anxiety. The Scale consists of 33 items which are rated on a 5-point Likert scale ranging from 1 ('strongly disagree') to 5 ('strongly agree'). The FLCAS is intended to assess three types of performance anxieties related to foreign language anxiety, namely: Communication apprehension (items 1, 4, 9, 14, 15, 18, 24, 27, 29, 30 and 32), test anxiety (items 3, 5, 6, 8, 10, 11, 12, 16, 17, 20, 21, 22, 25, 26 and 28), and fear of negative evaluation (items 2, 7, 13, 19, 23, 31 and 33). An anxiety score is calculated for each respondent by adding up their scores on the 33 items. Total scores on the FLCAS range from 33 (low level of anxiety) to 165 (high level of anxiety). Reverse coding is carried out for negatively worded items $(T=9)$ so, in all instances, a high score indicates a high degree of anxiety.

The third section of the questionnaire asked participants to state the formative itinerary or specialised education programme (Educational Support, Language and Audition, Foreign Language (English), etc.) they intended to follow. Participants were also asked to report their feelings towards the English language course (whether they liked it or not), as well as towards the use of the target language in class (whether they felt either confident or, on the contrary, anxious or nervous while using the L2).

Respondents took approximately 25 minutes to complete the questionnaire during a regular class period time. The quantitative data collected were analysed with the Statistical Package for the Social Sciences (SPSS) 22.0. The internal consistency measure of the FLCAS in this study was .92, which is very similar to the Cronbach's alpha coefficient of the Scale obtained by Horwitz et al. (1986) in their study $(\square=.93)$. The results, therefore, indicate a high level of internal consistency for the present sample (75 respondents).

\section{Results and discussion}

\subsection{What level of FLCA do prospective primary school teachers have towards the learning of English?}

Total scores were calculated for each respondent in order to assess their level of FLA towards the learning of English. Anxiety scores in this study ranged from 54 to 141 points. Participants were then classified into one of the three following groups according to their level of language anxiety: high anxiety, average or moderate 
anxiety, and low anxiety. The mean language anxiety score (M) of the Scale for the 75 participants was 105.06, and the standard deviation (SD) was 21.87. Following other studies (Tum, 2012; Öztürk, 2016), respondents who obtained scores of more than one standard deviation $(\mathrm{SD}=21.87)$ above the general mean language anxiety score $(\mathrm{M}=105.06)$ were classified as students with high anxiety (i.e. scores between 127 and 141). Students with low anxiety were those whose scores were more than one SD below the M (i.e. scores between 54 and 83). Finally, students with average or moderate anxiety were those who obtained scores of one SD above and one SD below the M (i.e. scores between 84 and 126). Analysis of the descriptive data showed that the majority of pre-service teachers $(63.2 \%)$ appear to be moderately anxious in the language classroom. However, it is worth noting that $22.1 \%$ of the student teachers reported experiencing high levels of language anxiety as opposed to $14.7 \%$ of the respondents who admitted feeling low levels of anxiety. Therefore, overall, results indicate that $71.9 \%$ of the participants seemed to experience average and high levels of anxiety in the L2 classroom (Liu, 2006; Arnáiz \& Guillén, 2012; Tum, 2012).

\subsection{What is the main source of FLCA among future primary school teachers?}

In order to explore the main source of FLCA among participants, the mean scores and standard deviations were computed for each type of performance anxiety associated with FLCA, namely, communicative apprehension, test anxiety and fear of negative evaluation. The descriptive results reveal that communicative apprehension is awarded the highest mean score $(\mathrm{M}=3.39, \mathrm{SD}=.756)$, followed next by fear of negative evaluation $(\mathrm{M}=3.25, \mathrm{SD}=.874)$, and, finally, test anxiety $(\mathrm{M}=3.04, \mathrm{SD}=$ $.600)$.

Table 1 shows the mean and standard deviation for all the items on the general FLCA Scale (33 items). The findings have been arranged in descending order of importance (after responses to negative items were reverse-coded) so as to facilitate their interpretation. Therefore, in all cases, the highest scores represent a high level of FLCA. 
Table 1. Participants' level of FLCA

\begin{tabular}{|c|c|c|c|}
\hline Items: FLCA & $\mathrm{N}$ & Mean & SD \\
\hline $\begin{array}{l}\text { 10. I worry about the consequences of failing my } \\
\text { foreign language class. }\end{array}$ & 75 & 4.33 & 1.004 \\
\hline $\begin{array}{l}\text { 9. I start to panic when I have to speak without } \\
\text { preparation in language class. }\end{array}$ & 75 & 4.03 & 1.090 \\
\hline $\begin{array}{l}\text { 1. I never feel quite sure of myself when I am } \\
\text { speaking in my foreign language class. }\end{array}$ & 75 & 3.96 & 1.058 \\
\hline $\begin{array}{l}\text { 13. It embarrasses me to volunteer answers in my } \\
\text { language class. }\end{array}$ & 75 & 3.69 & 1.185 \\
\hline $\begin{array}{l}\text { 15. I get upset when I don't understand what the } \\
\text { teacher is correcting. }\end{array}$ & 75 & 3.61 & 1.150 \\
\hline $\begin{array}{l}\text { 33. I get nervous when the language teacher asks } \\
\text { questions which I haven't prepared in advance. }\end{array}$ & 75 & 3.60 & 1.151 \\
\hline $\begin{array}{l}\text { 12. In language class, I can get so nervous I forget } \\
\text { things I know. }\end{array}$ & 75 & 3.59 & 1.104 \\
\hline $\begin{array}{l}\text { 7. I keep thinking that the other students are better } \\
\text { at languages than I am. }\end{array}$ & 75 & 3.53 & 1.212 \\
\hline $\begin{array}{l}\text { 23. I always feel that the other students speak the } \\
\text { foreign language better than I do. }\end{array}$ & 75 & 3.52 & 1.143 \\
\hline $\begin{array}{l}\text { 24. I feel very self-conscious about speaking the } \\
\text { foreign language in front of other students. }\end{array}$ & 75 & 3.49 & 1.267 \\
\hline $\begin{array}{l}\text { 27. I get nervous and confused when I am speaking } \\
\text { in my language class. }\end{array}$ & 75 & 3.47 & 1. 119 \\
\hline $\begin{array}{l}18^{*} \text { I feel confident when I speak in foreign } \\
\text { language class. }\end{array}$ & 75 & 3.45 & 1.119 \\
\hline $\begin{array}{l}11^{*} \text { I don't understand why some people get so } \\
\text { upset over foreign language classes. }\end{array}$ & 75 & 3.39 & 1.312 \\
\hline $\begin{array}{l}\text { 26. I feel more tense and nervous in my language } \\
\text { class than in my other classes. }\end{array}$ & 75 & 3.36 & 1.382 \\
\hline $\begin{array}{l}\text { 30. I feel overwhelmed by the number of rules you } \\
\text { have to learn to speak a foreign language. }\end{array}$ & 75 & 3.35 & 1.180 \\
\hline
\end{tabular}


$22^{*}$. I don't feel pressure to prepare very well for

language class.

$\begin{array}{lll}75 & 3.33 & 1.057\end{array}$

6. During language class, I find myself thinking

about things that have nothing to do with the

$75 \quad 3.31$

1.134

course.

29. I get nervous when I don't understand every

word the language teacher says.

$\begin{array}{lll}75 & 3.27 \quad 1.308\end{array}$

$8^{*}$. I am usually at ease during tests in my language

class.

$\begin{array}{lll}75 & 3.20 & 1.193\end{array}$

20. I can feel my heart pounding when I'm going to

be called on in language class.

$\begin{array}{lll}75 & 3.19 & 1.270\end{array}$

$14^{*}$. I would not be nervous speaking the foreign

language with native speakers.

$\begin{array}{lll}75 & 3.16 & 1.272\end{array}$

$2^{*}$ I don't worry about making mistakes in language class.

75

3.09

1.377

25. Language class moves so quickly I worry about getting left behind.

$\begin{array}{lll}75 & 3.05 & 1.262\end{array}$

3. I tremble when I know that I'm going to be called on in language class.

$\begin{array}{lll}75 & 2.99 & 1.307\end{array}$

31. I am afraid that the other students will laugh at me when I speak the foreign language.

$\begin{array}{lll}75 & 2.92 & 1.402\end{array}$

$32 *$ I would probably feel comfortable around native speakers of the foreign language.

17. I often feel like not going to my language class.

$\begin{array}{lll}75 & 2.91 \quad 1.093\end{array}$

16. Even if I am well prepared for language class, I feel anxious about it.

$\begin{array}{lll}75 & 2.85 & 1.249\end{array}$

4. It frightens me when I don't understand what the teacher is saying in the foreign language.

$\begin{array}{lll}75 & 2.76 & 1.403\end{array}$

$28^{*}$ When I am on my way to language class, I feel very sure and relaxed.

19. I am afraid that my language teacher is ready to correct every mistake I make.

21. The more I study for a language test, the more confused I get. 
$5^{\star}$ It wouldn't bother me at all to take more foreign language classes.

\section{Overall mean $=105.06$}

${ }^{*}$ Reversed values: The highest scores represent at all times a high anxiety level.

As can be seen, three of the 7 highest-scoring items within the general Scale were related to communicative apprehension (items 9, 1, and 15). The other 4 items were associated with fear of negative evaluation (items 13, 33), and test anxiety (item 10 and 12). However, it is noteworthy that the top-ranking scoring item across the three types of anxiety scales (item 10: 'I worry about the consequences of failing my foreign language class', ' $x=4.33$ ) is associated with test-anxiety. Therefore, failing the $\mathrm{L} 2$ course is considered to be the most anxiety-inducing factor related to FLCA. This is clearly attributable to the pressure most student teachers feel to pass the English language course in order to satisfy the English language requirement (B2 level, CEFR) before graduation. In addition to this, the findings reveal that the main anxiety-provoking factors are associated with communicative apprehension and speaking anxiety: 'I start to panic when I have to speak without preparation in language class' (item 9, ' $\mathrm{x}=$ 4.03) and 'I never feel quite sure of myself when I am speaking in my foreign language class' (item $1, x^{2}=3.96$ ). Oral communication skills are also linked to fear of negative evaluation since using the L2 was found to cause embarrassment ('It embarrasses me to volunteer answers in my language class', item 13, 'x $=3.69$ ) and affect the self-image of many respondents ('I get nervous when the language teacher asks questions which I have not prepared in advance', item 33, 'x $=3.60$ ). These results concur with those of MacIntyre \& Gardner (1991) who state that communicative apprehension and fear of negative evaluation are two closely related types of anxiety constructs. In addition to item 10 related to test anxiety, many other respondents also regarded the practice and use of the L2 in class as a permanent test situation (see Gregersen \& Horwitz, 2002): 'In language class, I can get so nervous I forget things I know' (item 12, ' $\mathrm{x}=$ 3.59) and, consequently, ranked this aspect among the six top scoring items associated to FLCA. As can be observed, all the items of the Scale except for three (items 19, 21, and 5) were rated above 2.5 points on a 5-point scale, which indicates that respondents experienced a considerable degree of FLCA.

Overall, the data show that, in line with previous research findings (Al-Saraj, 2014; Aida, 1994; MacIntyre \& Gardner, 1991, 1994; Yang, 2012), most student teachers seem to feel self-conscious and experience negative feelings while communicating and using the L2 in class, which may result in embarrassment and apprehension for most of them. Furthermore, results indicate that participants are really concerned about not being able to fulfil the compulsory English language requirement before 
graduation, which may lead them to regard the English language classes as especially anxiety-inducing contexts.

\subsection{Are there any differences in the degree of FLCA that prospective primary school teachers experience across different formative itineraries or specialised education programmes?}

With regard to the main specialised subjects intended to be chosen by participants (third section of the questionnaire), results indicate that the most popular formative itineraries were Physical Education (27.5\%) and Language and Audition (24.6\%), followed by Educational Support (20.3\%), Foreign Language (English) (14.5\%), and, finally, Arts and Music (13.0\%).

An independent-sample t-test was used to determine whether there were significant differences in FLCA levels between respondents who intended to become future Primary school English teachers and those who were planning to follow other formative itineraries (Physical Education teachers, Language and Audition teachers, Educational Support teachers, and Arts and Music Education teachers). The data indicate there were significant differences $(t=-2.312, p=.024<.05)$ between both group of students. Prospective primary school English teachers $(\mathrm{M}=90.44, \mathrm{SD}=$ 19.61) experienced significantly lower levels of FLCA than future teachers specialising in other subjects $(\mathrm{M}=108.04, \mathrm{SD}=21.42)$. These results came as no surprise since pre-service primary school English teachers are expected to show a higher degree of motivation towards the learning of English than their fellow counterparts.

Interestingly, the independent $t$-test analysis conducted between participants who reported liking English and those who admitted not liking the course subject, that is, those by whom English was considered just a compulsory degree requirement, revealed statistically significant differences $(t=-3.019, p=.004<.05)$. Thus, participants who liked English $(\mathrm{M}=100.52, \mathrm{SD}=20.51)$ were found to be less anxious than students who did not like the subject $(\mathrm{M}=117.67, \mathrm{SD}=21.08)$. Furthermore, these differences were not only significant for the general anxiety Scale but also for the three different performance anxiety scales: communicative apprehension $(t=-3.191, p=.002<.05)$, fear of negative evaluation $(t=-2.204, p=.031<.05)$, and test anxiety $(t=-2.715$, $p=.008<.05)$. Therefore, the results of this study confirm that students who are unmotivated and who do not like the English language tend to feel more uncomfortable when using the L2, are likely to be more concerned about negative evaluations of their linguistic performance by others, and appear to be excessively worried about failing in test situations. These findings are consistent with that of other studies which advocate that motivated students experience lower degrees of FLCA than students who lack 
motivation (Clément et al., 1994; Liu \& Huang, 2011), highlighting the close links between FLCA and motivation to learn the target language.

\subsection{Is FLCA affected by participants' gender, and level of English language proficiency?}

An independent sample t-test was run to examine potential differences in terms of FLCA levels as a function of gender. In line with previous research findings (Aida, 1994; Bekleyen, 2009; Park \& French, 2013; Öztürk, 2016), the data showed that gender does not have a statistically significant effect on the level of FLCA, although female participants $(\mathrm{M}=105.53, \mathrm{SD}=21.87)$ reported a slightly higher mean level of FLCA than their male counterparts $(M=102.64, S D=22.80)$. Therefore, the null hypothesis that there is no difference in the level of FLCA across gender cannot be rejected.

On the contrary, participants' university entrance examination mark in the English Test (ET) was found to be a determining factor affecting FLCA. The oneway analysis of variance (ANOVA) (see Table 2 and 3) revealed that the results of the university entrance ET had a statistically significant effect on the level of FLCA reported by student teachers $(\mathrm{F}(2,58)=9.052, \mathrm{p}<.000, \square \mathrm{p} 2=.23)$. Although the sample effect size is relatively small (.23), the data indicated that the observed power, that is, the likelihood that the test will produce a significant result, was very strong (.96). Bonferroni post hoc tests (Table 4) showed that there was a significant difference in anxiety levels between respondents who obtained scores between 7 and 8.9 points on a 10-point scale in the university entrance ET $(\mathrm{T}=18.03 \%)$, and both those who achieved less than 5 points $(T=34.42 \%, p=.001)$ and those who obtained between 5 and 6.9 points $(T=47.55 \%, p=.001)$ in this examination. In other words, the higher the mark in the ET, the lower the level of FLA experienced by participants. None of the respondents were awarded more than 8.9 points in the ET. In fact, it is a cause of great concern that a considerable number of student teachers $(T=34.42 \%)$ did not pass the ET at A2-B1 level of English proficiency (CEFR) to enter the university. The lack of proficiency in English may lead prospective teachers to experience high levels of FLCA since these students are aware of the fact that they need to demonstrate a B2 level of English proficiency in the four traditional language skills (reading, writing, speaking and listening) at the end of their second year of study in the Teacher Training Faculty (UIB). 
Table 2. Test of homogeneity of Variances

\begin{tabular}{lccc}
\hline $\begin{array}{l}\text { Levene } \\
\text { Statistic }\end{array}$ & df1 & df2 & Sig \\
\hline 2.251 & 2 & 58 & .114 \\
\hline
\end{tabular}

Table 3. ANOVA

\begin{tabular}{lccccc}
\hline & Sum of Squares & df & $\begin{array}{c}\text { Mean } \\
\text { Square }\end{array}$ & F & Sig. \\
\hline Between Groups & 6791.890 & 2 & 3395.945 & 9.052 & .000 \\
\hline Within Groups & 21759.094 & 58 & 375.157 & & \\
\hline Total & 28550.984 & 60 & & & \\
\hline
\end{tabular}

Table 4. Post hoc test. Bonferroni

Dependent variable: TOTALFLCA

Bonferroni

\begin{tabular}{|c|c|c|c|c|c|c|}
\hline \multirow{2}{*}{$\begin{array}{l}\text { (I) mark in } \\
\text { the SUEE** }\end{array}$} & \multirow{2}{*}{$\begin{array}{l}\text { (J) mark in the } \\
\text { SUEE }\end{array}$} & \multirow{2}{*}{$\begin{array}{c}\text { Mean } \\
\text { Difference } \\
(\mathrm{I}-\mathrm{J})\end{array}$} & \multirow{2}{*}{$\begin{array}{l}\text { Std } \\
\text { Error }\end{array}$} & \multirow{2}{*}{ Sig. } & \multicolumn{2}{|c|}{$\begin{array}{l}\text { 95\% Confidence } \\
\text { Inetrval }\end{array}$} \\
\hline & & & & & $\begin{array}{l}\text { Lower } \\
\text { Bound }\end{array}$ & $\begin{array}{l}\text { Upper } \\
\text { Bound }\end{array}$ \\
\hline \multirow{2}{*}{ less than 5} & $\begin{array}{c}\text { between } 5 \text { and } \\
6.9\end{array}$ & 2.718 & 5.550 & 1.000 & -10.97 & 16.40 \\
\hline & $\begin{array}{c}\text { between } 7 \text { and } \\
8.9\end{array}$ & $28.840^{*}$ & 7.209 & .001 & 11.07 & 46.61 \\
\hline \multirow[b]{2}{*}{$\begin{array}{l}\text { between } 5 \\
\text { and } 6\end{array}$} & less than 5 & -2.718 & 5.550 & 1.000 & -16.40 & 10.97 \\
\hline & $\begin{array}{c}\text { between } 7 \text { and } \\
8.9\end{array}$ & $26.122^{*}$ & 6.859 & .001 & 9.21 & 43.03 \\
\hline \multirow{2}{*}{$\begin{array}{l}\text { between } 7 \\
\text { and } 8\end{array}$} & less than 5 & $-28.840^{*}$ & 7.209 & .001 & -46.61 & -11.07 \\
\hline & $\begin{array}{c}\text { between } 5 \text { and } \\
6.9\end{array}$ & $-26.122^{*}$ & 6.859 & .001 & -43.03 & -9.21 \\
\hline
\end{tabular}

* The mean difference is significant at the 0.05 .

**SUEE: Spanish University Entrance Examination 
In any event, these results seem to confirm the strong link between proficiency and anxiety, and are congruent with other research findings that suggest that language proficiency in the L2 is a strong predictor of language teaching anxiety (Horwitz et al., 1986; Matsuda \& Gobel, 2003; Phillips, 2003; Elkhafaifi, 2005; Kongchan \& Wareesiri, 2008; Gagliardi \& Maley, 2010).

\section{5. What are the main sources of FLCA reported by student teachers when using the English language?}

Finally, participants were asked to specify their degree of confidence while using the target language in class. The data reveal that the majority of student teachers $(\mathrm{T}=55,73.3 \%)$ admitted feeling nervous or anxious when doing oral communication tasks in the context of the $\mathrm{L} 2$ classroom, as opposed to a small minority of respondents ( $\mathrm{T}=19,25.3 \%$ ) who reported feeling confident. Only 1 participant did not answer this question (1.3\%). Furthermore, a $t$-test analysis was carried out to determine the relationship between degree of confidence and FLCA. The findings indicate that there were statistically significant differences between both group of participants $(t=-4.840$, $\mathrm{p}=.000<.05)$. Thus, confident students $(\mathrm{M}=86.12, \mathrm{SD}=16.03)$ were found to suffer from lower levels of FLCA than nervous or anxious students $(\mathrm{M}=111.86, \mathrm{SD}=19.80)$.

In order to obtain a deeper understanding of the data, respondents were also asked to provide the main causes of their anxiety during oral communication tasks (Table 5). The main categories identified (see Nunan, 1992) were the following:

Table 5. Sources of speaking anxiety

\begin{tabular}{lcc}
\hline Responses & Frequency & Percentage \% \\
\hline - Little practice in speaking tasks. & 3 & 5.27 \\
- Lack of vocabulary and grammar knowledge. & 5 & 8.77 \\
- Lack of English proficiency. & 25 & 43.85 \\
- Fear of committing mistakes. & 7 & 12.28 \\
- Poor pronunciation. & 4 & 7.02 \\
- Inadequacy of previous education. & 1 & 1.75 \\
- Self-consciousness, fear of being laughed at. & 3 & 5.27 \\
- Test anxiety. & 2 & 3.51 \\
- Blank-mind anxiety when being forced to speak. & 5 & 8.77 \\
- Costly registration fees. & 2 & 3.51 \\
Total & 57 & 100 \\
\hline
\end{tabular}


As can be seen, the majority of respondents who admitted feeling anxious or nervous while using the L2 in class $(\mathrm{T}=55,73.3 \%)$ thought their level of anxiety stemmed mainly from their overall lack of proficiency in the target language (see also Matsuda \& Gobel, 2004; Tanaka \& Ellis, 2003; Cheng et al., 1999; Clément et al., 1994). More specifically, pre-service teachers emphasised their limited knowledge of grammar, vocabulary and pronunciation, which led them to feel too nervous and selfconscious when having to express themselves in the L2. In fact, some authors (Horwitz, 1996; Tum, 2010, 2012) point out that a limited and insufficient command of the English language is likely to cause feelings of linguistic apprehension and insecurity, which may lead L2 teachers to develop chronic feelings of anxiety. Therefore, the findings of this study concur with that of other researchers who highlight the close relationship between language teaching anxiety, self-confidence, and L2 proficiency (Yashima, 2002; Matsuda \& Gobel, 2004; Kongchan \& Wareesiri, 2008; Koul et al., 2009; Gagliardi \& Maley, 2010; Mak, 2011; Aydin, 2016).

Other causes of anxiety mentioned by participants were: fear of committing mistakes, lack of language skills to convey their intended messages, and fear of being an object of laughter or being ridiculed by their fellow mates, which is clearly associated with fear of negative evaluation as an anxiety construct. Further sources of anxiety highlighted by respondents were related to instructional methodologies, such as lack of sufficient practice in oral tasks or inadequacy of previous education. Participants' personal characteristics, such as fear of going blank when being forced to speak were also reported, suggesting that speaking in public and being put on the spot are considered major anxiety-inducing factors for L2 speakers (Young, 1990; Ewald, 2007). Finally, language tests, as well as the costly registration fees involved when failing the language course were also found to contribute to a lesser extent to potential causes of language anxiety.

\section{Conclusion}

The main purpose of this study was to explore FLCA experienced by prospective primary school teachers in relation to the teaching and learning of English as a foreign language. In accordance with previous research findings, this study provides evidence that the majority of prospective teachers $(T=63.2 \%)$ experience moderate levels of FLCA (Liu, 2006; Arnáiz \& Guillén, 2012; Tum, 2012; Elaldi, 2016; Öztürk, 2016). However, a considerable number of student teachers (22.1\%) also admit feeling highly anxious in the English classroom. The data revealed that the main source of FLCA is associated with communicative apprehension, followed next by fear of negative evaluation and, finally, test anxiety. Thus, student teachers report feeling selfconscious and uneasy when using the L2 in class. This seems to be closely related 
to the excessive concern participants feel about being evaluated negatively by others, which has detrimental effects on the practice and development of their communicative skills. These findings are consistent with those of other studies (MacIntyre \& Gardner, 1991) which point to the strong relationship between these two anxiety constructs: communicative apprehension and fear of negative evaluation. However, it is worth noting that the data show that failing the English language course is the most anxietyinducing factor across the three main types of anxiety scales. This is clearly attributable to the pressure prospective teachers feel to pass the language course in order to fulfill the compulsory graduation requirement in English at B2 level (CEFR) for all undergraduates, regardless of their chosen specialized subjects (Physical Education, Tutorial Action, English Language teaching, etc.).

The data from this study also confirmed other research findings that suggest close links between FLCA and motivation (Liu \& Huang, 2011; Clément et al. 1994). Thus, participants who chose to specialize in English, and who liked the English language course, reported experiencing statistically significant lower levels of FLCA across the three performance scales: communicative apprehension, fear of negative evaluation, and test anxiety. On the contrary, no statistically significant differences were found between FLCA and gender (see also Aida, 1994; Bekleyen, 2009; Park \& French, 2013; Öztürk, 2016), although female participants exhibited a slightly higher level of FLCA than their male counterparts. The findings also revealed that the university entrance examination mark in the English Test (ET) was found to be a determining factor affecting FLCA. ANOVA results showed statistically significant differences in anxiety levels between both those respondents who obtained scores between 7 and 8.9 points on a 10-point scale, and those who were awarded less than 5 points and between 5 and 6.9 points in this latter examination. This indicates that FLA tends to increase as L2 proficiency decreases. The fact that a considerable number of student teachers (34.42\%) did not pass the ET at A1-B1 English level (CEFR) in the university entrance examination should also be a cause of great concern, since these students will have to demonstrate a B2 level of English proficiency in the four traditional language skills (reading, writing, speaking and listening) at the end of their second year of study in the Teacher Training Faculty (UIB). This may constitute a major cause of FLCA since the results of this study show that language proficiency in the target language is a significant predictor of prospective teachers' anxiety (see also Horwitz et al., 1986; Matsuda \& Gobel, 2003; Phillips, 2003; Elkhafaifi, 2005; Kongchan \& Wareesiri, 2008; Koul et al., 2009; Gagliardi \& Maley, 2010; Mak, 2011). Likewise, the findings suggest that confidence is a major variable affecting FLCA. Thus, confident students experienced statistically lower levels of FLCA than nervous or anxious students. The data also indicated that the primary source of speaking anxiety was mainly related to participants' limited command of the English language, with special emphasis on 
particular areas such as grammar, vocabulary and pronunciation. According to some authors (Horwitz, 1996; Kim \& Kim, 2004), feelings of linguistic insecurity in the L2 and lack of confidence may negatively affect L2 teachers' ability to interact in the target language. These results are also consistent with that of other researchers who highlight close links between language teaching anxiety, self-confidence, and L2 proficiency (Clément et al., 1994; Cheng et al., 1999; Tanaka \& Ellis, 2003; Kim \& Kim, 2004; Matsuda \& Gobel, 2004). Therefore, as Horwitz (1996: 370) advocates: "we must be supportive of prospective foreign language teachers as they prepare to enter the profession; we do not want to perpetuate feelings of anxiety in future generations of language learners and teachers".

Overall, the findings of this study highlight the importance of FLCA in relation to L2 teaching and learning. Since FLCA has clearly shown to have adverse effects on L2 achievement as well as on L2 teachers' instructional practices and personal well-being (Horwitz, 1996; Kim \& Kim, 2004; Bekleyen, 2009; Tum, 2012), all necessary steps should be taken to ensure the promotion of more supportive and successful learning environments that may help student teachers to increase their motivation, improve their L2 proficiency and enhance their self-confidence in the use and development of the L2 in order to relieve the debilitating effects of FLA.

\section{References}

Aida, Y. (1994) Examination of Horwitz, Horwitz \& Cope's construct of Foreign Language Anxiety: The case of students of Japanese. The Modern Language Journal 78(2): $155-168$.

Al-Saraj, T. M. (2014) Revisiting the foreign language classroom anxiety scale (FLCAS): The anxiety of female English language learners in Saudi Arabia. L2 Journal 6: $50-76$.

Aydin, S. (2016) A qualitative research on foreign language teaching anxiety. The Qualitative Report 21(4): 629 - 642.

Amengual-Pizarro, M. (2013) Primary education degrees in Spain: Do they fulfill the linguistic and pedagogic needs of future teachers? Vigo International Journal of Applied Linguistics (VIAL) 10: 9- 27.

Arnaiz, P. and Guillén, F. (2012) Foreign language anxiety in a Spanish university setting: Interpersonal differences. Revista de Psicodidáctica 17(1): 5- 26.

. (2013) Anxiety in Spanish EFL students in different university degree programmes. Anales de Psicología 29(2): 335-344. 
Bekleyen, N. (2009) Helping teachers become better English students: Causes, effects, and coping strategies for foreign language listening anxiety. System 37: 664-675.

Casado, M. A. \& Dereshiwsky, M. I. (2001) Foreign language anxiety of university students. College Student Journal, 35(4): 539-551.

Clément, R., Dörnyei, Z. \& Noels, K. (1994) Motivation, self-confidence and group cohesion in the foreign language classroom. Language Learning 44: 417-448.

Cheng, Y, S., Horwitz, E. K. \& Shallert, D, L. (1999) Language anxiety: Differentiating writing and speaking components. Language Learning 49: 417-446.

Council of Europe. (2001) Common European Framework of Reference for Languages: Learning, Teaching, Assessment. Cambridge: Cambridge University Press.

Criado, R. \& Mengual, Y. (2017) Anxiety and EFL speaking in Spanish compulsory and non-compulsory secondary education: A mixed method study. Miscelánea: A Journal of English and American studies 55: 13-35.

Dewaele, J-M. (2005). Investigating the psychological and emotional dimensions in instructed language learning: obstacles and possibilities. The Modern Language Journal 89(3): 367- 380 .

Dörnyei, Z. (2005) The psychology of the language learner: Individual differences in second language acquisition, Mahwah, NJ: Lawrence Erlbaum Associates.

Elaldi, S. (2016) Foreign language anxiety of students studying English language and literature: A sample from Turkey, Educational Research and Reviews 11(2): 219- 228.

Elkhafaifi, H. (2005) Listening comprehension and anxiety in the Arabic language classroom. Modern Language Journal 89(2): 206 - 220.

Ewald, J. D. (2007) Foreign language learning anxiety in upper-level classes: Involving students as researchers. Foreign Language Annals 40(1): 122-142.

Gagliardi, C. \& Maley, A. (2010) EIL, EFL, Global English: Teaching and learning issues. Linguistic insights. Switzerland: Bern.

Gregersen, T. S \& Horwitz, E.K. (2002) Language learning and perfectionism: Anxious and non-anxious language learners' reactions to their own oral performance. The Modern Language Journal 86(4): 562 - 570.

Gregersen, T. S. (2003) To err is human: A reminder to teachers of languageanxious students. Foreign Language Annals 36(1): 25 - 32.

. (2007) Breaking the code of silence: A study of teachers' nonverbal decoding accuracy of foreign language anxiety. Language Teaching Research 1(2): 209221. 
Horwitz, E. K. (1996) Even teachers get the blues: Recognizing and alleviating language teachers' feeling of foreign language anxiety. Foreign Language Annals 29(3): 365-372.

. (2000) It ain't over 'till it's over: On foreign language anxiety, first language deficits, and the confounding of variables. The Modern Language Journal 84: $256-259$.

. (2001) Language anxiety and achievement. Annual Review of Applied Linguistics 21: 112- 126.

Horwitz, E. K. Horwitz, M, B. \& Cope, J. (1986) Foreign language classroom anxiety. The Modern Language Journal 70: 125- 132.

Horwitz, E, K. \& Young, D.J. (eds). (1991) Language Anxiety: From theory and practice to classroom implications. Englewood Cliffs, NJ: Prentice-Hall,

Ípek, J. H. 2007. Foreign language teaching anxiety. EskiПehir: T.C. Anadolu Üniversitesi Yayınları, No: 1730.

Kim, S. Y. (2009) Questioning the stability of foreign language classroom anxiety and motivation across different classroom contexts. Foreign Language Annals, 42(1): $138-157$.

Kim, S.Y. \& Kim, J.H. (2004). When the learner becomes a teacher: Foreign language teaching anxiety as an occupational hazar. English Teaching 59(1): 165 - 186.

Kongchan, C. \&. Wareesiri, W. (2008) Teacher's anxiety using L2 in EFL classrooms. Proceedings of the $16^{\text {th }}$ Annual Korea TESOL International Conference: Responding to a changing world. 2008. Seoul, Korea. 145 -149.

Koul, R., Roy, L., Kaewkuekool, S. \& Ploisawaschai, S. (2009) Multiple goal orientations and foreign language anxiety. System 37: 676- 688.

Krashen, S. D. (1985) The input hypothesis: Issues and implications. New York: Longman.

Liu, H. J. (2013) Effects of Foreign Language Anxiety and Perceived Competence on Learning Strategy Use. International Journal of English Linguistics 3(3): 76- 87.

Liu, M. (2006) Anxiety in Chinese EFL students at different proficiency levels. System 34(3): $301-316$.

Liu, M. \& Huang, W.. (2011) An Exploration of Foreign Language Anxiety and English Learning Motivation. Education Research International, vol. 2011, Article ID 493167, 8 pages.

MacIntyre, P. D. (1999) Language anxiety: A review of the research for language teachers. In D. J. Young (ed.) Affect in foreign language and second language learning: A 
practical guide to creating a low-anxiety classroom atmosphere. Boston: McGraw-Hill. 2445.

MacIntyre, P. D. \& Gardner, R. (1991) Methods and results in the study of anxiety and language learning: A review of literature. Language Learning 41: 85- 117.

. (1994) The subtle effects of language anxiety on cognitive processing in the second language. Language Learning 44: 283- 305.

Mak, B. (2011) An exploration of speaking-in-class anxiety with Chinese ESL learners".System, 39(2): 202- 214.

Martínez Agudo, J. (2013) An investigation into Spanish EFL learner's anxiety. RBLA, Belo Horizonte, 13(3): 829-851.

Matsuda, S. \& Gobel, P. (2004) Anxiety and predictors of performance in the foreign language classroom. System 32 (1): $21-36$.

Nunan, D. (1992) Research methods in language learning, Cambridge: Cambridge University Press.

Onwuegbuzie, A. J., Bailey, P. \&. Daley,C.E. (2000) Cognitive, affective, personality, and demographic predictors of foreign-language achievement. The Journal of Educational Research 94: 3- 15.

Ortega-Cebreros, A. (2003). Measuring language anxiety perceived by Spanish university students of English. Bells: Barcelona English language and literature studies, 12, Retrieved from http://www,raco,cat/index,php/bells/article/ viewArticle/82928/0/

Öztürk, G. (2016) Foreign language teaching anxiety among non-native teachers of English: A sample from Turkey. Sakarya University Journal of Education 6 (3): 54 - 70.

Park, G-P. \& French, B. F. (2013) Gender differences in the Foreign Language Classroom Anxiety Scale. System, 41(2): 462-471.

Pavlenko, A. (ed.).(2011) Thinking and speaking in two languages. Clevedon, UK: Multilingual Matters.

Pérez-Paredes, P. \& Martínez-Sánchez, F. (2000-2001) A Spanish version of the foreign language classroom anxiety scale: Revisiting Aida's factor analysis. Revista Española de Lingüística Aplicada RESLA 14: 337- 352.

Phillips, E. M. (1992) The effects of language anxiety on students' oral test performance and attitudes. The Modern Language Journal, 76: 14- 26.

Phillips, J. (2003) Foreign languages, literatures, cultures: Moving toward unity. ADFL Bulletin 35 (1): 15 -19. 
Rodríguez, M. \& Abreu, O. (2003) The stability of general foreign language classroom anxiety across English and French. The Modern Language Journal, 87 (3): $365-374$.

Sheen, Y. (2008) Recasts, language anxiety, modified output, and L2 learning. Language Learning 58 (4): 835-874.

Scovel, T. (2001) Learning new languages: A guide to second language acquisition. Boston: Heinle \& Heinle.

Spielman, G. \& Radnofsky, M. (2001) Learning language under tension: New directions from a qualitative study. The Modern Language Journal, 85: 259- 278.

Tanaka, K. \& Ellis, R. (2003) Study abroad, language proficiency, and learner beliefs about language learning JALT Journal 25: 63-85.

Tum, D. O. (2010) A study of non-native teachers' and student teachers' feelings of foreign language teaching anxiety (Unpublished Master's Thesis); The University of Texas, Austin.

. (2012) Feelings of language anxiety amongst non-native student teachers. Procedia Social and Behavioural Sciences 47: 2055 - 2059,

Yang, H.C. (2012) Language Anxiety: From the classroom to the community. English Teaching and Learning 36 (4): 1- 28.

Yashima, T. (2002) Willingness to communicate in a second language: The Japanese EFL context. The Modern Language Journal 86 (1), 54- 66.

Young, D. J. (1990) An investigation of students' perspectives on anxiety and speaking Foreign Language Annals 23: 539-553.

- (1992) Language anxiety from the foreign language specialist's perspective: Interviews with Krashen, Omaggio Hadley, Terrell, and Rardin. Foreign Language Annals 19: 439 - 445.

Williams, L. S. (1991) The effects of a comprehensive teaching assistant training program on teaching anxiety and effectiveness. Research in Higher Education 32 (5): 585 - 598.

Williams, K. E. \& Andrade, M.R. (2008) Foreign language learning anxiety in Japanese EFL university classes: Causes, coping, and locus of control. Foreign Language Teaching: 5(2): $181-191$.

Woodrow, L. (2006) "Anxiety and speaking English as a second language". RELC Journal 37(3), 308-328.

Zheng, Y. (2008). Anxiety and Second/Foreign language learning revisited. Canadian Journal for New Scholars in Education 1(1): 1 - 12. 